\title{
Efektivitas dan Efisiensi Pencatatan efek Opioid pada Pasien Pascaoperasi di RSUP Dr. Sardjito, Indonesia
}

\author{
Mahmud, ${ }^{1}$ Sri Rahardjo, ${ }^{2}$ Rama Iqbal Mahendra, ${ }^{3}$ Titania Juwitasari, ${ }^{4}$ Siti Khamdiyah, ${ }^{5}$ Retno \\ Koeswandari ${ }^{6}$ \\ ${ }^{1-4}$ Departemen Anestesiologi dan Terapi Intensif, 5,6Bagian Keperawatan ${ }^{1-6}$ Fakultas Kedokteran, \\ Kesehatan Masyarakat, dan Keperawatan Universitas Gadjah Mada/RSUP Dr. Sardjito, Yogyakarta
}

\begin{abstract}
Abstrak
Nyeri merupakan pengalaman sensoris dan emosional yang tidak menyenangkan terkait dengan kerusakan jaringan aktual atau potensial. Nyeri dapat terjadi saat preoperasi, durante, dan pascaoperasi. Pada umumnya, manajemen nyeri intra dan pascaoperasi menggunakan opioid. Penelitian ini bertujuan menilai efektivitas dan efisiensi pencatatan evaluasi penggunaan opioid intraoperatif dan pascaoperasi dan dilaksanakan pada Maret-Oktober 2019 di RSUP Dr. Sarjito Yogyakarta. Penelitian ini menggunakan desain kohort retrospektif untuk melihat efektivitas dan efisiensi pemberian opioid intraoperatif terhadap efek analgesia pascaoperasi dengan mengukur skala NRS, prevalensi kejadian efek samping opioid post-operative nausea and vomiting (PONV), recovery room length of stay (LOS), serta penggunaan obat analgetik pascaoperasi. Pencatatan rekam medis yang kurang lengkap sehingga tidak dapat menilai efektivitas penggunaan opioid intraoperatif yang baik. Penggunaan opioid pascaoperasi memiliki hubungan yang bermakna dengan skor NRS 12 jam pascaoperasi dan kejadian komplikasi $(\mathrm{p}=0,025 ; \mathrm{p}=0,028)$. Penggunaan opioid intraoperatif maupun pascaoperasi terhadap skor NRS, kejadian komplikasi, maupun lamanya waktu rawat di recovery room tidak terdapat hubungan yang bermakna. Simpulan, pencatatan evaluasi penggunaan opioid intraoperatif dan pascaoperasi di rekam medis masih belum lengkap. Penggunaan opioid intraoperatif tidak bermakna dalam menurunkan skor NRS, menurunkan kejadian komplikasi pascaoperasi, memperpendek lama rawat di recovery room, namun apabila opioid dilanjutkan pemberian pascabedah menurunkan NRS, tetapi efek samping opioid lebih tinggi.
\end{abstract}

Kata kunci: Length of stay, nyeri, numeric rating scale, opioid

\section{Effectiveness and Efficiency of Opioid Effects Recording in Postoperative Patients at Sardjito General Hospital, Indonesia}

\begin{abstract}
Pain is "an unpleasant sensory and emotional experience associated with actual or potential tissue damage. Postoperative pain is a pain felt by patients after a series of operations. In general, intraoperative and postoperative pains are treated with an opioid. This study aimed to determine the effectiveness and efficiency of recording evaluation of intraoperative and postoperative opioid use in patients. This study used a retrospective cohort design to identify the effectiveness and efficiency of intraoperative opioid administration on the postoperative analgesia effect by measuring the NRS scale, the prevalence of side effects of postoperative nausea and vomiting (PONV), Recovery Room length of stay (LOS), and the administration of postoperative analgesics. Due to incomplete medical records, it cannot assess the effectiveness of a good intraoperative opioid. Postoperative opioid use has a significant correlation with NRS score 12 hours postoperatively and the complication incidence $(p=0.025, p=0.028)$. There was no significant relationship between either intraoperative or postoperative opioids to NRS score, adverse events, and length of stay in the Recovery Room. In conclusion, the recording of pain management in intraoperative and postoperative opioid use in the medical record is still incomplete. The intraoperative opioids use does not significantly reduce the NRS score, decrease the postoperative complications, and shorten the length of stay in the Recovery Room. If opioids are continued, postoperative administration significantly lower NRS; however, the side effects of opioids are higher.
\end{abstract}

Key words: Length of stay, numeric rating scale, opioid, pain

Korespondensi: Mahmud, dr., Bagian Anestesiologi dan Terapi Intensif Fakultas Kedokteran, Kesehatan Masyarakat, dan Keperawatan Universitas Gajah Mada/RSUP Dr. Sardjito Yogyakarta, Jl. Kesehatan No. 1 Sekip Yogyakarta, Email mahmudanestesi@mail.ugm.ac.id 


\section{Pendahuluan}

Nyeri adalah pengalaman sensoris dan emosional yang tidak menyenangkan terkait dengan kerusakan jaringan aktual atau potensial, atau dijelaskan dalam istilah kerusakan tersebut yang "direkomendasikan oleh Sub-komite Taksonomi dan diadopsi oleh Dewan IASP pada tahun 1979. ${ }^{1}$ Nyeri pascaoperasi merupakan nyeri yang dirasakan oleh pasien setelah menjalani serangkaian proses operasi. Menurut Joint Commission on Accreditation of Health Organizations (JCAHO), nyeri merupakan tanda vital kelima dan perlu dilakukan tata laksana nyeri pada pasien pasca operasi. ${ }^{2}$ Pada umumnya, nyeri pasca operasi dinilai menggunakan skor numeric rating scale (NRS). Pasien diminta menyebutkan skor nyeri yang dirasakan menggunakan skala 10 angka, dengan angka 0 berarti tidak nyeri dan angka 10 berarti nyeri terburuk yang dapat dirasakan. NRS merupakan instrumen penilaian nyeri yang valid dan juga reliabel. Beberapa pedoman menyarankan skor NRS $>4$ sebagai cut-off untuk memberikan analgetik, termasuk opioid. ${ }^{3-5}$

Skor NRS yang tinggi tidak secara mutlak merefleksikan keinginan pasien untuk mendapatkan terapi analgetik tambahan, terutama ketika opioid ditawarkan kepada pasien. Penelitian yang dilakukan van Dijk $\mathrm{dkk}^{3}$ tentang perbandingan skor NRS dengan verbal rating scale (VRS) menunjukkan bahwa pasien yang merasakan nyeri, namun mampu ditahan (bearable pain) dapat diasumsikan tidak menginginkan tambahan obat opioid. ${ }^{3}$ Di RSUP Dr. Sardjito mayoritas pasien mendapatkan terapi analgetik multimodal dengan termasuk di dalamnya pemberian opioid. Akan tetapi, belum pernah dilakukan evaluasi efektivitas dan efisiensi pemberian opioid pascaoperasi. dengan melihat berbagai parameter dan membandingkannya dengan literatur terkini di RSUP Dr. Sardjito.

Para peneliti pertama kali menggambarkan kemungkinan hubungan antara kerusakan jaringan intraoperatif dan intensifikasi nyeri akut dan nyeri pascaoperasi jangka panjang yang sekarang disebut sebagai sensitisasi sentral. Aktivasi nociceptor dimediasi oleh bahan kimia yang dilepaskan sebagai respons terhadap kerusakan sel atau jaringan. Analgesia pre-emptive merupakan konsep penting dalam memahami strategi pengobatan untuk analgesia pascaoperasi. Analgesia preemptive berfokus pada pengendalian nyeri pascaoperasi serta pencegahan sensitisasi sentral dan nyeri neuropatik kronis dengan memberikan analgesia yang diberikan sebelum operasi, tetapi tidak setelah insisi bedah. Penelitian tambahan dalam analgesia preemptive diperlukan untuk lebih menentukan pengukuran hasil yang baik dan penilaian yang lebih baik terkait dengan optimasi pengobatan. $^{6}$

Analgesi multimodal merupakan suatu manajemen nyeri dengan memberikan dua atau lebih obat atau kombinasi dua atau lebih modalitas manajemen nyeri yang memiliki mekanisme aksi yang berbeda dengan target organ yang berbeda yang akan memodulasi nyeri. Kombinasi dua atau lebih agen atau teknik dengan mekanisme efek analgesi yang beragam dapat memberikan respons yang sinergis dan dapat memberikan efikasi yang lebih baik dalam manajemen nyeri. Hal tersebut dapat mengurangi dosis obat yang diberikan, termasuk dosis opioid dan dapat mengurangi efek samping yang muncul. ${ }^{7}$

Dokumentasi pada manajemen nyeri pascaoperasi juga merupakan salah satu langkah penting dalam pelayanan manajemen nyeri. Rekam medis tersebut memberikan informasi penting bagi tim tenaga kesehatan untuk memberikan manajemen nyeri. Dokumentasi pelayanan pada rekam medis ini juga diperlukan untuk evaluasi kualitas pelayanan yang diberikan pada pasien. ${ }^{8}$

Saat ini, pencatatan penilaian/evaluasi nyeri dan pencatatan obat yang diberikan pascaoperasi masih sering tidak lengkap. Penelitian sebelumnya juga masih kurang dokumentasi penilaian nyeri dan tata laksana nyeri pada pasien pascaoperasi. ${ }^{9}$

Berangkat dari latar belakang ini, peneliti ingin melakukan evaluasi penggunaaan opioid pada pasien intra dan pascaoperasi, kemudian dilakukan evaluasi pada catatan rekam medis. 


\section{Subjek dan Metode}

Penelitian ini menggunakan desain kohort retrospektif dari rekam medis untuk melihat efektivitas dan efisiensi penggunaan opioid pascaoperasi untuk mengukur skala NRS, prevalensi kejadian efek samping opioid post operative nausea and vomiting (PONV), hospital length of stay (LOS), serta penggunaan obat analgetik pascaoperasi. Penelitian ini dilaksanakan pada bulan Maret-Oktober 2019 bertempat di RSUP Dr. Sarjito Yogyakarta. Konsep multimodal analgesia dipergunakan dengan meminimalkan pemberian opioid untuk mencapai efektifnya opioid.

Populasi target penelitian ini adalah seluruh pasien yang menjalani operasi elektif di RSUP Dr. Sardjito. Sampel penelitian ini adalah seluruh pasien yang terjadwal operasi elektif dengan menggunakan anestesi umum maupun regional di RSUP Dr. Sardjito sejak bulan Juli-September 2019. Kriteria inklusi pasien meliputi: 1) pasien pascaoperasi di RSUP Dr Sardjito dalam kurun waktu JuliSeptember 2019; 2) memiliki minimal 2 (dua) dari parameter berikut yang tercantum dalam rekam medis pasien: usia, jenis kelamin, BMI, data obat anestesi, dosis, nilai NRS, dan waktu lama rawat. Kriteria eksklusi pasien meliputi: 1) pasien yang langsung dirawat di Intensive Care Unit (ICU) dan pasien yang menjalani operasi one day care; 2) data rekam medis pasien yang tidak lengkap mencakup minimal dua parameter yang diinginkan dalam penelitian ini. Pengumpulan data dilakukan pada bulan Juli - September 2019. Total sampel yang didapatkan sebanyak 273 rekam medik. Rekam medik yang memenuhi kriteria inklusi sebanyak 228 rekam medik. Sebanyak 45 rekam medis lainnya tidak memiliki minimal dua parameter yang tercantum dalam rekam medis. Sebanyak 84 rekam medis memiliki tujuh parameter yang sudah disebutkan di atas.

Definisi operasional penelitian ini, antara lain post operative nausea and vomiting (PONV) adalah kejadian mual dan muntah pada pasien yang muncul dalam 24-48 jam setelah operasi pada pasien rawat inap. Nyeri adalah keadaaan emosional yang tidak menyenangkan yang dirasakan oleh pikiran, tetapi dapat diidentifikasi berasal dari bagian tubuh tertentu atau dapat dikatakan sebagai sensasi subjektif. Nyeri yang dimaksudkan dalam penelitian ini adalah nyeri yang muncul pada bagian tubuh pasien yang menjalani prosedur operasi. Length of stay pasien di recovery room yang dimaksud dalam penelitian ini adalah selisih antara waktu selesai operasi dan waktu pasien diterima di kamar bangsal perawatan.

Penelitian mendapat persetujuan etik dari KomisiEtikFK-KMKUGMNomor KE/FK/1061/ $\mathrm{EC} / 2019$. Instrumen yang digunakan dalam penelitian ini adalah formulir pengambilan data untuk dilengkapi saat mencari di rekam medis pasien yang sudah disimpan di Instalasi Catatan Medik RSUP Dr. Sardjito.

Semua data dikumpulkan dan dimasukkan ke dalam database menggunakan aplikasi Microsof Office Excel 2013 dan aplikasi IBM SPSS Statistics V21. Data dianalisis menggunakan statistik deskriptif. Analisis bivariat mempergunakan chi-square dengan tingkat kesalahan 5\% dan tingkat kepercayaan 95\% pada variabel opioid dengan nilai NRS, lama rawat, dan komplikasi yang ditampilkan pada Tabel 5 dan Tabel 6. Analisis multivariat menggunakan regresi logistik berganda pada variabel penggunaan opioid disertai variabel karakteristik responden dengan nilai NRS, lama rawat, dan komplikasi yang ditampilkan pada Tabel 7 dan 8.

\section{Hasil}

Jumlah sampel yang didapatkan selama pengumpulan data sebanyak 273 rekam medik. Rekam medik yang dikategorikan lengkap jika memiliki tujuh parameter (usia, jenis kelamin, BMI, data obat anestesi, dosis, nilai NRS, dan waktu lama rawat) yang tercatat. Didapatkan 84 rekam medik yang lengkap dan 189 rekam medis yang tidak lengkap. Jumlah rekam medik yang memenuhi kriteria inklusi (memiliki minimal dua parameter yang tercatat dalam rekam medis) sebanyak 228 rekam medis. 
Tabel 2 Distribusi Frekuensi Karasteristik Responden

\begin{tabular}{lcc}
\hline \multicolumn{1}{c}{ Variabel } & $\begin{array}{c}\text { Frekuensi } \\
\text { (n=228) }\end{array}$ & $\begin{array}{c}\text { Persentase } \\
\text { (\%) }\end{array}$ \\
\hline Usia & & \\
Anak & 13 & 5,7 \\
Dewasa & 154 & 67,5 \\
Lansia & 61 & 26,8 \\
Jenis kelamin & & \\
Laki-laki & 118 & 51,8 \\
Perempuan & 110 & 48,2 \\
Klasifikasi BMI & & \\
$\quad$ Underweight & 37 & 16,2 \\
Normal & 126 & 55,3 \\
Overweight & 65 & 28,5 \\
\hline
\end{tabular}

Tabel 1 menunjukkan presentase rekam medis yang memiliki kelengkapan data berupa tercatat tujuh parameter yang diinginkan oleh peneliti (usia, jenis kelamin, BMI, data obat anestesi, dosis, nilai NRS, dan waktu lama rawat).

Berdasar atas temuan pada Tabel 1 terkait kelengkapan data RM, terlihat bahwa pencatatan data riwayat pasien pascaoperasi di RSUP Dr. Sardjito masih belum lengkap. Hasil penelusuran menunjukkan masih kurang pencatatan pengawasan pascaoperasi pasien yang mendapatkan obat analgesia baik opioid maupun nonopioid, baik tidak lengkap pencatatan skor NRS setiap jam pascaoperasi, komplikasi, keakuratan length of stay di recovery room, maupun data pendukung lain yang seharusnya lengkap dicatat di dalam RM. Tabel 2 menunjukkan terdapat 67,5\% sampel berusia dewasa dan 55,3\% sampel memiliki nilai BMI yang normal. Adapun persentase berdasar atas jenis kelamin didapatkan hampir seimbang.

Tabel 3 menunjukkan distribusi obat anestesi intraoperatif yang didapatkan oleh sampel. Dari 228 sampel, 138 sampel (60,5\%) mendapatkan obat analgesi intraoperatif golongan opioid, dengan 135 di antaranya mendapat fentanil. Dosis obat opioid yang
Tabel 3 Distribusi Frekuensi Obat Anestasi yang Digunakan $(n=228)$

\begin{tabular}{|c|c|c|}
\hline Obat Anestesi & $\begin{array}{l}\text { Frekuensi } \\
\text { (f) }\end{array}$ & $\begin{array}{c}\text { Persentase } \\
(\%)\end{array}$ \\
\hline \multicolumn{3}{|l|}{ Golongan } \\
\hline Opioid & 138 & 60,5 \\
\hline Nonopioid & 90 & 39,5 \\
\hline \multicolumn{3}{|l|}{ Jenis obat anestesi } \\
\hline Fentanil & 135 & 59,2 \\
\hline Tramadol & 1 & 0,4 \\
\hline Petidin & 2 & 0,9 \\
\hline Nonopioid & 90 & 39,5 \\
\hline \multicolumn{3}{|c|}{ Dosis obat opioid (mcg) } \\
\hline 10 & 1 & 0,4 \\
\hline 25 & 7 & 3,1 \\
\hline 50 & 13 & 5,7 \\
\hline 60 & 1 & 0,4 \\
\hline 75 & 10 & 4,4 \\
\hline 80 & 1 & 0,4 \\
\hline 85 & 1 & 0,4 \\
\hline 100 & 70 & 30,7 \\
\hline 125 & 7 & 3,1 \\
\hline 150 & 20 & 8,8 \\
\hline 175 & 1 & 0,4 \\
\hline 200 & 4 & 1,8 \\
\hline 250 & 1 & 0,4 \\
\hline 275 & 1 & 0,4 \\
\hline \multicolumn{3}{|c|}{ Jumlah obat anestesi } \\
\hline 1 Jenis & 183 & 80,3 \\
\hline 2 Jenis & 39 & 17,1 \\
\hline 3 Jenis & 6 & 2,6 \\
\hline \multicolumn{3}{|c|}{ Kebutuhan opioid pascaoperasi } \\
\hline Butuh & 57 & 25,0 \\
\hline Tidak butuh & 171 & 75,0 \\
\hline
\end{tabular}

paling sering diberikan intraoperatif pasien sebanyak $100 \mathrm{mcg}(30,7 \%) .80,3 \%$ sampel mendapatkan 1 jenis obat anestesi serta $75 \%$ sampel tercatat tidak membutuhkan tambahan opioid pascaoperasi.

Hasil tersebut menunjukkan bahwa fentanil lebih sering digunakan dengan efek 
Tabel 4 Distribusi Frekuensi Kejadian Komplikasi, NRS, dan RR

\begin{tabular}{|c|c|c|}
\hline Variabel & $\begin{array}{l}\text { Frekuensi } \\
\text { (f) }\end{array}$ & $\begin{array}{c}\text { Persentase } \\
\text { (\%) }\end{array}$ \\
\hline \multicolumn{3}{|l|}{ Komplikasi } \\
\hline Ada & 20 & 8,8 \\
\hline Tidak ada & 208 & 91,2 \\
\hline \multicolumn{3}{|l|}{ Jenis komplikasi } \\
\hline PONV & 9 & 45 \\
\hline Nyeri kepala & 1 & 5 \\
\hline Nyeri perut & 1 & 5 \\
\hline Gangguan bak & 3 & 15 \\
\hline Konstipasi & 4 & 20 \\
\hline Gatal dan ruam & 1 & 5 \\
\hline \multicolumn{3}{|l|}{ NRS 1 jam } \\
\hline Sedang-berat & 12 & 5,3 \\
\hline Ringan & 126 & 55,2 \\
\hline Tidak terlaporkan & 90 & 39,5 \\
\hline \multicolumn{3}{|l|}{ NRS 2 jam } \\
\hline Sedang-berat & 7 & 31,1 \\
\hline Ringan & 140 & 61,4 \\
\hline Tidak terlaporkan & 81 & 35,5 \\
\hline \multicolumn{3}{|l|}{ NRS 12 jam } \\
\hline Sedang-berat & 3 & 1,3 \\
\hline Ringan & 154 & 67,5 \\
\hline Tidak terlaporkan & 71 & 31,2 \\
\hline \multicolumn{3}{|l|}{ NRS 24 jam } \\
\hline Ringan & 147 & 64,5 \\
\hline Tidak terlaporkan & 81 & 35,5 \\
\hline \multicolumn{3}{|l|}{ RR } \\
\hline$>60$ menit & 152 & 66,7 \\
\hline$<60$ menit & 51 & 22,4 \\
\hline Tidak terlaporkan & 25 & 11,0 \\
\hline
\end{tabular}

analgesia tertentu yang lebih dipilih oleh anestesiologis. Namun, penggunaan fentanil yang lebih dipilih ini juga dapat merupakan akibat dari pencatatan yang tidak lengkap maupun regulasi penggunaan opioid yang lebih rigid.

Pada Tabel 4 terlihat bahwa komplikasi pascaoperasi didapatkan pada 20 sampel $(8,8 \%)$ dengan jenis komplikasi terbanyak
PONV (45\%). Adapun persentase tingkat nilai NRS pada 1, 2, 12, atau 24 jam pascaoperasi didapatkan paling banyak tercatat pada kategori ringan (>50\%). Sebanyak 66\% sampel memiliki lama rawat di recovery room selama $>60$ menit.

Tabel 5 menunjukkan perbandingan nilai NRS pascaoperasi antara pasien yang mendapatkan analgesi opioid dan non-opioid intraoperatif serta perbandingan nilai NRS pascaoperasi pada kebutuhan opioid. Pada perbandingan analgesi intraoperatif, lebih dari 90\% sampel yang mendapat opioid maupun nonopioid tercatat memiliki NRS kategori ringan, baik pada penilaian 1 jam, 2 jam, 12 jam, maupun 24 jam pascaoperasi. Pada perbandingan kebutuhan opioid pascaoperasi didapatkan lebih dari $75 \%$ sampel tercatat memiliki NRS kategori ringan di semua waktu penilaian. Lebih dari 30\% sampel tidak memiliki data lengkap mengenai nilai NRS, maupun kebutuhan opioid pascaoperasi.

Pada Tabel 5 terlihat tidak ada hubungan yang signifikan antara pengunaan opioid intraoperatif dan tingkatan NRS pada semua waktu penilaian. Hasil signifikan didapatkan pada perbandingan nilai NRS 1 jam dan 2 jam pascaoperasi terhadap kebutuhan opioid pascaoperasi.

Tabel 6 menunjukkan perbandingan lama rawat dan komplikasi pada kelompok golongan analgesi intraoperatif yang didapatkan serta perbandingan lama rawat dan komplikasi berdasar atas kebutuhan opioid pascaoperasi. Tidak ada hubungan penggunaan opioid intraoperatif, baik opioid maupun nonopioid dengan lama rawat dan komplikasi. Hal ini dapat dilihat bahwa penggunan opioid dan nonopioid intraoperatif mempunyai perbandingan persentase lama rawat dan komplikasi yang hampir sama, sedangkan berdasar atas kebutuhan opioid terdapat hubungan signifikan kebutuhan opioid dengan komplikasi.

Pada Tabel 7 terlihat bahwa hanya variabel penggunaan opioid pascaoperatif yang berhubungan signifikan dengan nilai NSR 1 jam dan variabel jumlah obat anestesi yang digunakan dengan lama rawat pasien. 
Tabel 5 Tabulasi Silang Penggunaan Opioid dengan Nilai NRS

\begin{tabular}{|c|c|c|c|c|c|c|c|c|c|c|c|c|c|c|c|c|}
\hline \multirow{3}{*}{$\begin{array}{l}\text { Penggunaan } \\
\text { Opioid }\end{array}$} & \multicolumn{4}{|c|}{ NRS 1 Jam } & \multicolumn{4}{|c|}{ NRS 2 Jam } & \multicolumn{4}{|c|}{ NRS 12 Jam } & \multicolumn{4}{|c|}{ NRS 24 Jam } \\
\hline & \multicolumn{2}{|c|}{$\begin{array}{c}\text { Sedang- } \\
\text { Berat }\end{array}$} & \multicolumn{2}{|c|}{ Ringan } & \multicolumn{2}{|c|}{$\begin{array}{c}\text { Sedang- } \\
\text { Berat }\end{array}$} & \multicolumn{2}{|c|}{ Ringan } & \multicolumn{2}{|c|}{$\begin{array}{c}\text { Sedang- } \\
\text { Berat }\end{array}$} & \multicolumn{2}{|c|}{ Ringan } & \multicolumn{2}{|c|}{$\begin{array}{c}\text { Sedang- } \\
\text { Berat }\end{array}$} & \multicolumn{2}{|c|}{ Ringan } \\
\hline & $\mathbf{n}$ & $\%$ & $\mathbf{n}$ & $\%$ & $\mathbf{n}$ & $\%$ & $\mathbf{n}$ & $\%$ & $\mathbf{n}$ & $\%$ & $\mathbf{n}$ & $\%$ & $\mathbf{n}$ & $\%$ & $\mathbf{n}$ & $\%$ \\
\hline \multicolumn{17}{|l|}{ Intraoperatif } \\
\hline Nonopioid & 3 & 6,5 & 43 & 93,5 & 2 & 3,8 & 50 & 96,2 & 1 & 1,8 & 56 & 98,2 & 0 & 0,0 & 56 & 100 \\
\hline Opioid & 9 & 9,8 & 83 & 90,2 & 5 & 5,3 & 90 & 94,7 & 2 & 2,0 & 98 & 98,0 & 0 & 0,0 & 91 & 100 \\
\hline Nilai p & \multicolumn{4}{|c|}{0,749} & \multicolumn{4}{|c|}{1,000} & \multicolumn{4}{|c|}{1,000} & \multicolumn{4}{|c|}{-} \\
\hline \multicolumn{17}{|l|}{ Pascaoperatif } \\
\hline Butuh & 10 & 21,3 & 37 & 78,7 & 7 & 15,2 & 39 & 84,8 & 2 & 3,9 & 49 & 96,1 & 0 & 0,0 & 48 & 100 \\
\hline $\begin{array}{l}\text { Tidak } \\
\text { butuh }\end{array}$ & 2 & 2,2 & 89 & 97,8 & 0 & 0,0 & 101 & 100 & 1 & 0,9 & 105 & 99,1 & 0 & 0,0 & 99 & 100 \\
\hline Nilai p & \multicolumn{4}{|c|}{0,000} & \multicolumn{4}{|c|}{0,000} & \multicolumn{4}{|c|}{0,247} & \multicolumn{4}{|c|}{ - } \\
\hline $\begin{array}{l}\text { Tidak } \\
\text { tercatat }\end{array}$ & \multicolumn{4}{|c|}{$90(39,5 \%)$} & \multicolumn{4}{|c|}{$81(35,5 \%)$} & \multicolumn{4}{|c|}{$71(31,1 \%)$} & \multicolumn{4}{|c|}{$81(35,5 \%)$} \\
\hline
\end{tabular}

Uji multivariat dilanjutkan untuk variabel dependen nilai NSR 2 jam, NSR 12 jam, dan komplikasi.

Pada Tabel 8 terlihat bahwa regresi logitik pada variabel NSR 1 jam tidak dapat dilakukan. Hal ini disebabkan oleh hasil uji bivariat ditemukan sel yang bernilai 0. Adapun hasil regresi logistik pada variabel nilai NSR 12 jam dapat disimpulkan bahwa nilai NSR 12 jam ditentukan oleh pertama opioid pascaoperatif dan kedua yang paling dominan adalah faktor kategori BMI. Hasil serupa dengan variabel
NSR 12 jam ditemukan pada hasil analisis regresi logistik variabel komplikasi.

\section{Pembahasan}

Studi ini menunjukkan pencatatan evaluasi pemberian opioid intraoperatif dan pascaoperasi pada rekam medis masih belum lengkap. Selain itu, didapatkan hasil yang tidak signifikan pada hubungan pemberian opioid intraoperatif terhadap penurunan skor NRS kejadian komplikasi maupun memperpendek

Tabel 6 Tabulasi silang penggunaan opioid dengan lama rawat dan komplikasi

\begin{tabular}{|c|c|c|c|c|c|c|c|c|}
\hline \multirow{3}{*}{ Penggunaan Opioid } & \multicolumn{4}{|c|}{ Lama rawat } & \multicolumn{4}{|c|}{ Komplikasi } \\
\hline & \multicolumn{2}{|c|}{$>60$ Menit } & \multicolumn{2}{|c|}{$<60$ Menit } & \multicolumn{2}{|c|}{ Tidak Ada } & \multicolumn{2}{|c|}{ Ada } \\
\hline & $\mathbf{n}$ & $\%$ & $\mathbf{n}$ & $\%$ & $\mathbf{n}$ & $\%$ & $\mathbf{n}$ & $\%$ \\
\hline \multicolumn{9}{|l|}{ Intraoperatif } \\
\hline Nonopioid & 61 & 74,4 & 21 & 25,6 & 81 & 90,0 & 9 & 10,0 \\
\hline Opioid & 91 & 75,2 & 30 & 24,8 & 127 & 92,0 & 11 & 8,0 \\
\hline Nilai $\mathrm{p}$ & \multicolumn{4}{|c|}{1,000} & \multicolumn{4}{|c|}{0,637} \\
\hline \multicolumn{9}{|l|}{ Pascaoperatif } \\
\hline Butuh & 37 & 75,5 & 12 & 24,5 & 48 & 84,2 & 9 & 15,8 \\
\hline Tidak butuh & 115 & 74,7 & 39 & 25,3 & 160 & 93,6 & 11 & 6,4 \\
\hline Nilai p & \multicolumn{4}{|c|}{1,000} & \multicolumn{4}{|c|}{0,031} \\
\hline Tidak tercatat & \multicolumn{4}{|c|}{$25(11,0 \%)$} & \multicolumn{4}{|c|}{$0(0,0 \%)$} \\
\hline
\end{tabular}


Tabel 7 Regresi Logistik Proses Seleksi Analisis Multivariat

\begin{tabular}{lccccc}
\hline \multicolumn{1}{c}{ Variabel } & NSR1 & NSR2 & NSR12 & Lama Rawat & Komplikasi \\
\hline Opioid pascaoperatif & $0,000^{*}$ & $0,000^{*}$ & $0,202^{*}$ & 0,907 & $0,031^{*}$ \\
Opioid intraoperatif & 0,522 & 0,700 & 0,914 & 0,895 & 0,597 \\
Jenis opioid & 0,718 & 0,840 & 0,995 & 0,627 & 0,506 \\
Dosis opioid & 0,261 & 0,804 & 0,582 & 0,951 & $0,196^{*}$ \\
Jumlah obat anestesi & 0,553 & $0,247^{*}$ & 0,388 & $0,017^{*}$ & $0,214^{*}$ \\
Kategori usia & 0,571 & $0,204^{*}$ & 0,488 & 0,528 & $0,217^{*}$ \\
Jenis kelamin & 0,667 & 0,940 & 0,676 & 0,653 & 0,271 \\
Kategori BMI & 0,361 & 0,309 & $0,240^{*}$ & 0,285 & $0,106^{*}$ \\
\hline
\end{tabular}

Keterangan: *) lolos seleksi dilanjutkan uji multivariat jika lebih dari variabel indpenden

lama rawat pasien di recovery room. Namun, berdasar atas hasil regresi logistik, didapatkan hubungan yang signifikan pada pemberian opioid pascaoperatif dengan nilai NRS 12 jam pascaoperatif dan komplikasi.

Penelitian sebelumnya oleh Karmena

Tabel 8 Regresi Logistik Variabel Independen dengan NSR 2 Jam, NSR 12 Jam, dan Komplikasi

\begin{tabular}{|c|c|c|c|c|c|c|}
\hline \multirow{2}{*}{ Variabel } & \multirow{2}{*}{ B } & \multirow{2}{*}{ S.E. } & \multirow{2}{*}{ Sig. } & \multirow{2}{*}{$\operatorname{Exp}(B)$} & \multicolumn{2}{|c|}{$95 \%$ CI for EXP (B) } \\
\hline & & & & & Lower & Upper \\
\hline \multicolumn{7}{|c|}{ Langkah awal NSR 2 jam } \\
\hline Opioid pascaoperatif & 19,509 & $3.869,292$ & 0,996 & $296.821 .648,295$ & 0,000 & \\
\hline Jumlah obat anestesi & $-0,803$ & 0,758 & 0,289 & 0,448 & 0,101 & 1,978 \\
\hline Kategori usia & $-1,084$ & 0,837 & 0,195 & 0,338 & 0,066 & 1,746 \\
\hline \multicolumn{7}{|c|}{ Langkah akhir NSR 2 Jam } \\
\hline Opioid pascaoperatif & 19,485 & 3999,351 & 0,996 & $289.956 .996,196$ & 0,000 & \\
\hline Konstanta & $-17,768$ & 3999,351 & 0,996 & 0,000 & & \\
\hline \multicolumn{7}{|l|}{ Langkah NSR 12 Jam } \\
\hline Opioid pascaoperatif & $-1,325$ & 0,592 & 0,025 & 0,266 & 0,083 & 0,848 \\
\hline Kategori BMI & 0,996 & 0,486 & 0,040 & 2,708 & 1,045 & 7,013 \\
\hline Konstanta & $-2,503$ & 1,337 & 0,061 & 0,082 & & \\
\hline \multicolumn{7}{|c|}{ Langkah pertama komplikasi } \\
\hline Opioid pascaoperatif & $-0,991$ & 0,532 & 0,062 & 0,371 & 0,131 & 1,052 \\
\hline Dosis opioid & 0,003 & 0,004 & 0,494 & 1,003 & 0,995 & 1,011 \\
\hline Jumlah obat anestesi & 0,554 & 0,434 & 0,201 & 1,741 & 0,744 & 4,071 \\
\hline Kategori usia & 0,653 & 0,484 & 0,178 & 1,920 & 0,744 & 4,958 \\
\hline Kategori BMI & 0,708 & 0,401 & 0,078 & 2,031 & 0,925 & 4,458 \\
\hline \multicolumn{7}{|c|}{ Langkah akhir komplikasi } \\
\hline Opioid pascaoperatif & $-1,069$ & 0,485 & 0,028 & 0,343 & 0,133 & 0,889 \\
\hline Kategori BMI & 0,662 & 0,384 & 0,085 & 1,938 & 0,913 & 4,114 \\
\hline Konstanta & $-2,035$ & 1,142 & 0,075 & 0,131 & & \\
\hline
\end{tabular}


dkk. ${ }^{10}$ melakukan pengujian nilai NRS saat istirahat dan berbaring setelah pemberian kombinasi analgetik intravena pada jam ke- $1,2,4,6,8,16$, dan 24. Karmena dkk. ${ }^{10}$ mendapatkan hasil yang signifikan pada NRS 30 menit dan 24 jam pascaoperatif dengan posisi pasien istirahat. Kontrolnya DBD grade I dan II. Data asupan vitamin D diambil dengan food frequency questionnaire (FFQ Penelitian lain dengan 36 subjek yang menganalisis perbandingan pemberian analgesik intraoperatif dengan pascaoperatif terhadap nilai NRS mendapatkan hasil yang tidak signifikan. Nilai NRS yang didapatkan dari kedua kelompok mayoritas pada nilai ringan sedang dan tidak memerlukan analgetik tambahan pascaoperasi. ${ }^{11}$

Nilai NRS tidak dapat secara merata digunakan untuk membedakan pasien yang membutuhkan tambahan opioid atau tidak. Mayoritas pasien dengan skor NRS 8 atau lebih akan menginginkan tambahan opioid pascaoperasi. Alasan mengapa pasien dengan skor NRS sedang ( $>4$ ) tidak menginginkan opioid karena merasa masih dapat menahan rasa nyerinya dan tidak menginginkan efek samping atau komplikasi yang muncul berdasar atas pengalaman sebelumnya. ${ }^{3}$ Maka saat ini, opioid tidak lagi sebagai obat dasar dengan konsep multimodal analgesia opioid hanya sebagai rescue.

Karakteristik subjek pada penelitian ini paling banyak subjek usia dewasa, memiliki BMI normal, dan jumlah laki-laki lebih banyak dibanding dengan perempuan. Tighe dkk. ${ }^{12}$ menemukan jenis kelamin, usia, dan jenis operasi dapat memengaruhi nyeri postoperasi. Penelitian lain mendapatkan hasil perbedaan yang tidak signifikan antara nilai NRS dan jenis kelamin atau usia. ${ }^{13}$ Koh dkk. ${ }^{14}$ mendapatkan nilai NRS yang lebih tinggi pada pasien kelompok usia muda (20-39 tahun) dibanding dengan kelompok usia tua ( $>70$ tahun) pada 6-12 jam pascaoperasi. Namun, tidak ditemukan perbedaan yang signifikan pada kelompok interval waktu lainnya. Studi yang dilakukan oleh Grodofsky dan Sinha ${ }^{15}$ tidak terdapat perbedaan nilai NRS pascaoperasi yang signifikan antara kelompok BMI $<30$ $\mathrm{kg} / \mathrm{m}^{2}$ dan $\mathrm{BMI}>30 \mathrm{~kg} / \mathrm{m}^{2}$. Hubungan linear antara BMI dan NRS juga tidak signifikan.

Pada penelitian ini 8,8\% pasien mengalami komplikasi disebabkan oleh pemberian opioid pascaoperasi. Sembilan pasien di antaranya (45\%) mengalami komplikasi, yaitu berupa PONV. Lainnya memiliki komplikasi berupa konstipasi, gangguan BAK, atau yang lainnya. Pizzi $\mathrm{dkk}^{16}$ pada penelitiannya mendapatkan komplikasi yang paling sering terjadi atau dirasakan pasien setelah mendapatkan obat anestesi opioid adalah mual dan muntah. Selain mual dan muntah, komplikasi yang dapat muncul diantaranya konstipasi, ileus, retensi urin, pruritus, hipoksia, depresi napas, hipotensi, somnolens, bingung dan pusing. Yang dkk. ${ }^{17}$ mendapatkan hasil yang tidak signifikan terhadap insidensi komplikasi yang muncul setelah pemberian opioid pascaoperasi. Hal ini dapat juga dipengaruhi oleh perbedaan dosis opioid yang diberikan ataupun pengaruh faktor reseptor opioid. ${ }^{17}$

Kejadian mual dan muntah pascaoperasi sangat mengganggu pasien dan bertanggung jawab terhadap sistem sumber daya termasuk pemulihan yang tertunda, lama tinggal yang lama di area pemulihan dan rumah sakit, penerimaan yang tidak terduga, dan akhirnya peningkatan biaya layanan kesehatan. ${ }^{18}$

Ganter dkk. ${ }^{19}$ telah menyatakan dalam penelitiannya bahwa peningkatan insidensi PONV terdapat pada pasien skor nyeri yang lebih tinggi pada penilaian saat masuk PACU. Temuan ini dapat juga dikarenakan besar dosis yang diberikan pada pasien. Nyeri pascaoperasi merupakan faktor independen terhadap PONV. Pada penelitan ini juga didapatkan hubungan yang signifikan antara pemberian opioid pascaoperasi dan komplikasi. Manajemen pascaoperasi di PACU atau recovery room yang baik dan sesuai dapat mengurangi nyeri pascaoperasi dan PONV yang dialami oleh pasien. ${ }^{19}$ Penelitian Madere dkk. ${ }^{20}$ yang menganalisis pengaruh pemberian analgesik golongan asetaminofen maupun non-asetaminofen (morfin, fentanil, hidromorfon) pascaoperasi pada lamanya perawatan tidak menunjukkan perbedaan yang signifikan. ${ }^{20}$ 
Penelitian lain menunjukkan hasil yang signifikan pada pasien yang mendapatkan opioid preoperasi memiliki waktu perawatan yang lebih panjang dibanding dengan pasien yang tidak mendapatkan opioid. Nilai skala nyeri pasien, penggunaan opioid pascaoperasi dan risiko komplikasi dalam 30 hari pascaoperasi yang lebih tinggi pada pasien yang mendapatkan opioid preoperasi. ${ }^{21}$

Pada penelitian ini masih ditemukan ketidaklengkapan data pada rekam medis, terutama data yang berkaitan dengan pengawasan pascaoperasi pasien yang mendapatkan obat analgesik baik opioid maupun nonopioid, pencatatan nilai NRS tiap jam, komplikasi, maupun lama waktu rawat di recovery room. Erden dkk. ${ }^{9}$ saat meneliti rekam medis pasien 48 jam pascaoperasi menemukan bahwa tidak terdapat informasi mengenai penilaian nyeri seperti keparahan, tipe, durasi maupun nilai skala nyeri yang tercatat pada rekam medis. Pencatatan penilaian nyeri mengalami penurunan kepatuhan tiap jamnya, didapatkan $70,8 \%$ dua jam pascaoperasi masih tercatat, namun menurun hingga $42 \%$ setelah 24 jam pascaoperasi. Pada pedoman tatalaksana nyeri pascaoperasi dan studi lain merekomendasikan bahwa nyeri selalu dinilai secara berkala setelah pemberian analgesik. ${ }^{22}$ Ayasrah dkk. ${ }^{23}$ juga mendapatkan $37 \%$ rekam medis yang memiliki data penilaian nyeri setelah pemberian analgesik.

Penelitian ini berfokus pada efektivitas efisiensi pencatatan efek opioid terhadap pasien pascaoperasi di RSUP Dr. Sardjito. Peneliti dapat menilai kelengkapan dan kepatuhan petugas medis dalam pencatatan manajemen pasien di rekam medis sehingga dapat memberikan masukan untuk perbaikan mengenai pencatatan rekam medis pasien. Namun, peneliti tidak mengamati langsung pengaruh pemberian opioid intraoperasi terhadap nilai NRS, komplikasi yang muncul pascaoperasi dan lama waktu pasien di recovery room. Data yang didapatkan dari rekam medis ini masih ada kemungkinan tidak tercatat oleh petugas medis yang mengerjakan. Ketidaklengkapan data ini juga dapat disebabkan oleh jumlah tenaga medis yang memiliki tanggung jawab untuk melengkapi rekam medis serta alur pasien yang panjang.

Penelitian ini adalah tinjauan rekam medis retrospektif sehingga peneliti terbatas hanya mengamati apa yang didokumentasikan. Setiap efek samping yang tidak didokumentasikan oleh dokter tidak tercatat dalam penelitian ini. Selain itu, peneliti tidak membandingkan dan menganalisis pemberian analgesi multimodal lainnya. Penelitian ini terbatas pada penilaian pemberian opioid pada pasien intra dan pascaoperasi.

\section{Simpulan}

Diperlukan pertimbangan untuk direncanakan pencatatan RM secara elektronik. Jika masih menggunakan kertas maka perlu dilakukan perbaikan pencatatan RM pasien operasi terutama dengan mempertimbangkan pembuatan formulir RM baru khusus bagian anestesi dan pembagian peran yang rigid bagi tenaga medis yang bertanggungjawab melakukan pencatatan RM pasien operasi pada formulir RM anestesi tersebut. Sesuai dengan hasil penelitian ini maka untuk mengurangi lama rawat di RR, skor NRS dan komplikasi penggunaan opioid intraoperatif tetap memakai multimodal analgesia dengan opioid sebagai rescue.

\section{Daftar Pustaka}

1. Raja SN, Carr DB, Cohen M, Finnerup NB, Flor H, Gibson S, dkk. The revised International Association for the study of pain definition of pain: concepts, challenges, and compromises. Pain. 2020;161(9):1976-82.

2. Karcioglu O, Topacoglu H, Dikme O, Dikme 0 . A systematic review of the pain scales in adults: Which to use? [Internet]. Am J Emerg Med. W.B. Saunders; 2018;36:70714. http://www.ajemjournal.com/article/ S0735675718300081/fulltext.

3. van Dijk JFM, Kappen TH, Schuurmans MJ, van Wijck AJM. The relation between patients' NRS pain scores and their desire for additional opioids after surgery. Pain 
Pract. 2015;15(7):604-9.

4. Lazaridou A, Elbaridi N, Edwards RR, Berde CB. Pain assessment. Essentials of pain medicine [Internet]. 2018 [diunduh 21 Sept 2020]. Tersedia dari: https:// linkinghub.elsevier.com/retrieve/pii/ B978032340196800005X.

5. Walker BJ, Polaner DM, Berde CB. Acute pain. a practice of anesthesia for infants and children. New York: Elsevier; 2019.

6. Vadivelu N, Mitra S, Schermer E, Kodumudi V, Kaye AD, Urman RD. Preventive analgesia for postoperative pain control: a broader concept. Local Reg Anesth. 2014;7(1):1722.

7. Tubog TD. Overview of multimodal analgesia initiated in the perioperative setting. J Perioper Pract [Internet]. 2020 Jun 8 [diunduh 21 Sept 2020];175045892092884. Tersedia dari: http://journals.sagepub.com/ doi/10.1177/1750458920928843

8. Samuels JG, Kritter D. Pain management documentation: analyzing one hospital's computerized clinical records. CIN-Comput Informatics Nurs. 2011;29(9):512-8.

9. Erden S, Arslan S, Deniz S, Kaya P, Gezer D. A review of postoperative pain assessment records of nurses. Appl Nurs Res. 2017;38:1-4.

10. Karmena D, Oktaliansah E, Surahman E. Perbandingan kombinasi tramadol parasetamol intravena dengan tramadol ketorolak intravena terhadap nilai numeric rating scale dan kebutuhan opioid pascahisterektomi.JAP. 2015;3(3):189-95.

11. Yuswono ARA, Maskoen TT, Fuadi I. Perbandingan pemberian parecoxib na $40 \mathrm{mg}$ intravena preoperatif dengan pascaoperatifdalam penatalaksanaan nyeri pascaoperatif pada operasi laparotomi ginekologis. JAP. 2014;2(3):169-73.

12. Tighe PJ, Le-Wendling LT, Patel A, Zou B, Fillingim RB. Clinically derived early postoperative pain trajectories differ by age, sex, and type of surgery. Pain [Internet]. 2015 Apr 1 [diunduh $30 \mathrm{Sept}$ 2020];156(4):609-17. Tersedia dari: http://journals.lww.com/00006396-

\section{0-00007}

13. Chae KL, Park SY, Hong JI, Yim WJ, Lee SC, Chung CJ. The effect of gender and age on postoperative pain in laparoscopic cholecystectomy: a prospective observational study. Anesth Pain Med [Internet]. 2019 Jul 31 [diunduh 30 Sept 2020];14(3):364-9. Tersedia dari: https:// www.anesth-pain-med.org/journal/view. php?id=10.17085/apm.2019.14.3.364

14. Koh JC, Lee J, Kim SY, Choi S, Han DW. Postoperative pain and intravenous patient-controlled analgesia-related adverse effects in young and elderly patients. Medicine (Baltimore) [Internet]. 2015 Nov 1 [diunduh 1 Okt 2020];94(45):e2008. Tersedia dari: http://journals.lww.com/00005792201511110-00051.

15. Grodofsky S, Sinha A. The association of gender and body mass index with postoperative pain scores when undergoing ankle fracture surgery. J Anaesthesiol Clin Pharmacol [Internet]. 2014 [diunduh 15 okt 2020];30(2):248. Tersedia dari: http://www.joacp.org/text. asp?2014/30/2/248/130041

16. Pizzi LT, Toner R, Foley $\mathrm{K}$, Thomson E, Chow W, Kim M, dkk. Relationship between potential opioid-related adverse effects and hospital length of stay in patients receiving opioids after orthopedic surgery. Pharmacother J Hum Pharmacol Drug Ther [Internet]. 2012 Jun 1 [diunduh 21 Okt 2020];32(6):502-14. Tersedia dari: http://doi.wiley.com/10.1002/j.18759114.2012.01101.x

17. Yang Y, Wu J, Li H, Ye S, Xu X, Cheng L, dkk. Prospective investigation of intravenous patient-controlled analgesia with hydromorphone or sufentanil: Impact on mood, opioid adverse effects, and recovery. BMC Anesthesiol [Internet]. 2018 Apr 10 [diunduh 03 Nov 2020];18(1):37. Tersedia dari: https://bmcanesthesiol. biomedcentral.com/articles/10.1186/ s12871-018-0500-1

18. Frauenknecht J, Kirkham KR, JacotGuillarmod A, Albrecht E. Analgesic impact 
of intra-operative opioids vs. opioid-free anaesthesia: a systematic review and metaanalysis. Anaesthesia [Internet]. 2019 May 25 [diunduh 15 Nov 2020];74(5):651-62. Tersedia dari: https://onlinelibrary.wiley. com/doi/abs/10.1111/anae.14582

19. Ganter MT, Blumenthal S, Dübendorfer S, Brunnschweiler S, Hofer T, Klaghofer R, dkk. The length of stay in the post-anaesthesia care unit correlates with pain intensity, nausea and vomiting on arrival. Perioper Med [Internet]. 2014 Dec 26 [diunduh 30 Nov 2020];3(1):10. Tersedia dari: http:// www.perioperativemedicinejournal.com/ content $/ 3 / 1 / 10$

20. Madere TC, Mendez JB, Nordmeyer ST, Heidel RE, Hamilton LA. Evaluation of intravenous acetaminophen on length of stay in abdominal surgery patients. hosp pharm [Internet]. 2016 Mar 1 [diunduh 20 Des 2020];51(3):230-6. Tersedia dari: http://journals.sagepub.com/doi/ full/10.1310/hpj5103-230
21. Sing DC, Barry JJ, Cheah JW, Vail TP, Hansen EN. Long-acting opioid use independently predicts perioperative complication in total joint arthroplasty. J Arthroplasty [Internet]. 2016 Sep 1 [diunduh 24 Des 2020];31(9):170-4.e1. Tersedia dari: http://www.arthroplastyjournal.org/ article/S0883540316002552/fulltext

22. Gordon DB, Rees SM, McCausland MP, Pellino TA, Sanford-Ring S, SmithHelmenstine J, dkk. Improving reassessment and documentation of pain management. Jt Comm J Qual Patient Saf. 2008;34(9):509-17.

23. Ayasrah SM, O'neill TM, Abdalrahim MS, Sutary MM, Kharabsheh MS. Pain assessment and management in critically ill intubated patients in Jordan : a prospective study. Int J Health Sci (Qassim) [Internet]. 2014 Sep [diunduh 25 Des 2020];8(3):287-98. Tersedia dari: https://platform.almanhal.com/Details/ Article/84099 